\title{
9
}

\section{Moving From the Scholarship of Teaching and Learning to Educational Research: An Example From Engineering}

\author{
Ruth A. Streveler \\ Purdue University \\ Maura Borrego \\ Virginia Polytechnic Institute and State University \\ Karl A. Smith \\ University of Minnesoto
}

In The Advancement of Learning, Huber and Hutchings (2005) state that the "scholarship of teaching and learning ... is about producing knowledge that is available for others to use and build on" (p. 27). Can viewing the scholarship of teaching and learning (SoTL) as an educational research activity help make SoTL findings more available and easier to build on? This chapter describes a program that prepared engineering faculty to conduct rigorous research in engineering education. Project evaluation revealed that engineering faculty had difficulty making some of the paradigm shifts that were presented in the project.

The late Ernest Boyer (1990) introduced the scholarship of teaching as one of four interdependent dimensions of scholarship, with the scholarships of discovery, integration, and application rounding out the quartet. In the years since this work was published, the scholarship of teaching (now more commonly called the scholarship of teaching and learning, or So'TL) has 
taken hold, and the promotion of SoTL is often a major activity of faculty development centers (Sorcinelli, Austin, Eddy, \& Beach, 2006).

Involvement in SoTL usually begins with faculty's interest in how students in their own classrooms are learning (Huber \& Hutchings, 2005), and the purpose of SoTL is to improve learning by improving teaching (Boyer, 1990). Thus SoTL tends to be very personal and situated in one person's classroom. The very personal nature of SoTL might lead to context-specific results that could be difficult to generalize and apply to broader settings. In some disciplines, this may diminish the perceived impact or significance of results.

Recently, there have been calls for increasing the impact of SoTL results. Faculty have been urged to "go meta" with their studies and to look at broader questions of how students learn that go beyond the specifics of their individual classrooms (Hutchings \& Shulman, 1999; Schroeder, 2005). But what does "going meta" really mean? And what models can we provide to faculty to help them do this?

In engineering education, as in most disciplines, the majority of studies to this point have been classroom and curriculum focused. Several factors now point to the readiness of the engineering discipline to move from SoTL into the realm of engineering education research (Gabriele, 2005). Colleges of engineering have recently created new engineering education departments (Haghighi, 2005), and the premiere American journal in this field, the Journal of Engineering Education, has developed more stringent publication criteria (Felder, Sheppard, \& Smith, 2005). In order to support more rigorous studies in engineering education, the Center for the Advancement of Scholarship in Engineering Education was founded by the National Academy of Engineering, and the American Society for Engineering Education will sponsor a year of dialogue about scholarship in engineering education in 2006.

This chapter describes a program in engineering education that may be useful both as a mechanism to further the discussion of SoTL, and as a model that could be applicable to disciplines other than engineering.

\section{Conducting Rigorous Research in Engineering Education}

\section{Project Description}

The focus for this chapter is Conducting Rigorous Research in Engineering Education: Creating a Community of Practice, or the RREE project. The RREE project was funded by the National Science Foundation for three years to prepare three cohorts of 20 engineering faculty to conduct rigorous engineering education research. Each yearlong experience began with a summer 
workshop and was followed by each participant conducting a systematic engineering education research project throughout the year. The projects were often small scale and informal. However, they were intended to assist in building engineering education research capabilities.

Faculty participants came from institutions across the US and were required to apply to the RREE project. Participants paid for their travel to the RREE project site, but all other expenses, such as lodging, meals, and materials, were covered by the RREE budget. In 2004, selection was made on a firstcome, first-served basis. About 80 engineering faculty applied to be part of the RREE project during the week the application was posted to the project web site.

Due to the demand for participation, more stringent criteria for selection were created in 2005. Participants in 2005 were selected based on three criteria: 1) readiness to participate (including past involvement in engineering education conferences and projects, and the strength of research questions submitted as part of their application),2) the broader impact of participation (as evidenced by their role as a national or campus change agent, and their local and/or national involvement with groups who are underrepresented in engineering), and 3) the degree of support for engineering education research on their campus (based on the strength of a letter of support from their dean or department head, and campus policies that support engineering education research). Two project coordinators independently scored each application. Even with these stringent criteria, about 45 engineering faculty applied to be part of the 2005 RREE project.

The National Science Foundation funded the RREE project as a mechanism to prepare current engineering faculty to be part of this move. The RREE project provided preparation, guidance, and a community as part of a yearlong experience for engineering faculty. Following acceptance, participation began with an intense workshop experience, a five-day summer workshop held each year from 2004-2006.

The learning objectives of the summer workshop were:

- List and briefly describe important principles about how students learn, and especially how students learn engineering

- List and briefly describe common methods used in education research

- Read and interpret education research articles to inform an enginecring education

- Conduct informal or formal education research at their respective campuses 
An assumption of the RREE project was that in order to increase the rigor of engineering education research, engineering practitioners needed to learn the literature, methods, and paradigms of educational research. This project provided a structure and mechanism for preparing faculty to conduct rigorous engineering education research through a collaboration of engineering educators, faculty developers, and learning scientists.

- Engineering educators, the American Society for Engineering Education, the lead on this project

- Faculty developers in higher education, the Professional and Organizational Network in Higher Education

- Learning scientists, specifically the Education in the Professions Division of the American Educational Research Association

The executive committee, whose 10 members represented each of the three collaborating organizations, designed the RREE project workshops and follow-up activities, and selected facilitators from each organization. In 2004, the first year of the project, the committee chose to emphasize theories of student learning with the intention of helping participants apply educational research to improve their teaching. In the following two years, however, the focus shifted to conducting, not just using, the research, which was the real objective of the RREE project. To redesign the workshop accordingly, the executive committee decided to focus on three issues: 1) the paradigm shifts engineering faculty needed to make to conduct educational research (versus engineering research), 2) the knowledge and skills they needed, and 3) the best format for the training.

Paradigm shifts. Engineers use a consistent, implicit theoretical framework anchored in the laws of nature and a standardized methodology to conduct disciplinary research. Since they need not choose a theoretical or methodological perspective, they are typically unaware that research in other disciplines-among them, education-offer and in fact require choices among potentially useful approaches. Engineers are also highly practical. Those in the 2004 cohort were mostly interested in personal, classroom-based assessments of the teaching methods they were already using, with the hope of documenting that their methods "worked."

The redesigned workshop tackled paradigm shifts explicitly on the first day by emphasizing three distinctions. The first difference highlighted was between engineering research, which takes a standardized approach, and education research, which requires selecting an appropriate theoretical framework and methodology. The second key distinction made was between 
assessment, which finds out "what kind of" and "how much" learning, and research, which pursues "why" and "how" the learning comes about (Paulsen, 2001). The engineers in this project seemed more comfortable with the former than the latter. The final comparison explained were the differences among the levels of teaching rigor, as summarized in Table 9.1. Hutchings and Shulman (1999) propose the first three levels-excellent teaching, scholarly teaching, and the scholarship of teaching-and the RREE Executive Committee added the fourth: rigorous research in engineering education.

Cognitive apprenticeship. During the remaining four days, the workshop became a cognitive apprenticeship (Brown, Collins, \& Duguid, 1989; Collins, Brown, \& Newman, 1989). Facilitators modeled the steps of the educational research process-developing good research questions, choosing an appropriate theoretical framework, and selecting methods and measurementsusing examples out of engineering education. Then the participants worked in self-selected groups with similar research questions to develop a poster of the research design they planned to follow during the upcoming academic

TABLE 9.1

\section{Levels of Rigor in Inquiry About Teaching and Learning}

\begin{tabular}{|l|l|}
\hline Level of Inquiry & \multicolumn{1}{|c|}{ Attributes of That Level } \\
\hline $\begin{array}{l}\text { Level 1: Excellent } \\
\text { Teaching }\end{array}$ & Involves the use of good content and teaching methods \\
\hline $\begin{array}{l}\text { Level 2: Scholarly } \\
\text { Teaching }\end{array}$ & $\begin{array}{l}\text { Involves good content and methods and classroom assessment and evi- } \\
\text { dence gathering, informed by best practice and best knowledge, inviting } \\
\text { of collaboration and review }\end{array}$ \\
\hline $\begin{array}{l}\text { Level 3: Scholar- } \\
\text { ship of Teaching }\end{array}$ & $\begin{array}{l}\text { Is public and open to critique and evaluation, is in a form that others can } \\
\text { build on, involves question-asking, inquiry, and investigation, particu- } \\
\text { larly about student learning }\end{array}$ \\
\hline $\begin{array}{l}\text { Level 4: Rigorous } \\
\text { Research in } \\
\text { Engineering } \\
\text { Education }\end{array}$ & $\begin{array}{l}\text { Also is public, open to critique, and involves asking questions about stu- } \\
\text { dent learning, but it includes a few unique components: 1) Beginning } \\
\text { with a rescarch question, not an assessment question. Assessment ques- } \\
\text { tions deal with the "what" or "how much" of learning, while research } \\
\text { questions focus on the "why" or "how" of learning (Piulsen, 2001). 2) } \\
\text { Tying the question to learning, pedagogical, or social theory and inter- } \\
\text { preting the results of the research in light of theory and thereby allowing } \\
\text { research to build theory and yield significant findings. For example, } \\
\text { studies about teaching thernodynamics can be redesigned to become } \\
\text { studies, based on cognitive theory, which can help explain why certain } \\
\text { concepts in thermodynanics are so difficult to learn. 3) Paying careful } \\
\text { attention to design of the study and the methods used, adding validity, } \\
\text { reliability, and impact to the findings. }\end{array}$ \\
\hline
\end{tabular}


year. Both the workshop facilitators and fellow participants provided feedback on the posters. The grant provided modest funding for the research projects and for research mentors to advise participants on their research design and/or analysis.

\section{Assessment of the 2004 and 2005 Workshops}

The RREE grant was assessed every year using multiple strategies. The first strategy was a survey of the participations' satisfaction with various aspects of the five-day summer workshop. Table 9.2 displays the questions as well as the results from the 2004 and 2005 cohorts. While the average scores are quite similar overall, they differ appreciably on the goal attainment items that reflect the different foci of the two years. The 2004 engineers appraised their mastery of learning principles more highly than did the 2005 group, and this latter cohort considered their understanding of educational research methods stronger than did the former group.

The second assessment strategy was a pre-participation and post-participation survey of perceived knowledge gains. Table 9.3 shows the pre- and post-differences for the 2004 and 2005 cohorts, and they too reflect the change in emphasis from year to year. On most of the content familiarity items, the 2005 cohort reported greater gains, but not on most of the "more specific content knowledge" items, which the 2004 group learned just from acquiring familiarity with the literature. The results on the final question, which ask about one's comfort level designing education research, predictably favored the 2005 group.

An analysis of participant research journals, the third assessment strategy, revealed a shift from teaching to research issues from 2004 to 2005, and about a quarter of the 2005 entries addressed topics at the more rigorous, research-oriented end of the continuum shown earlier in Table 9.1.

The richest data, however, emerged from the fourth assessment strategy: evaluator observations of the 2005 workshop group discussions. How participants understood the generalizability of research studies reflected their appreciation of the distinction between SoTL and rigorous educational research. On the first day of the workshop they had disagreements, with some engineers contending that if research couldn't be generalized, it couldn't be good. Reflecting her discipline's approach to experimentation, one participant asked her discussion group, "If you do something in your classroom, isn't it automatically generalizable?" 
TABLE 9.2

Ratings Results: Participant Feedback, 2004 Versus 2005

\begin{tabular}{|c|c|c|}
\hline & 2004 & 2005 \\
\hline \multicolumn{3}{|l|}{ General Workshop Satisfaction } \\
\hline \multicolumn{3}{|l|}{ Scale: Excellent $=5$ through Poor $=1$} \\
\hline \multicolumn{3}{|l|}{ How would you rate the quality of the following: } \\
\hline Organization & 4.28 & 4.55 \\
\hline Comfort (room, temperature, food) & 4.67 & 4.27 \\
\hline Appropriateness of schedule pacing & 4.08 & 4.25 \\
\hline \multicolumn{3}{|l|}{ Program } \\
\hline \multicolumn{3}{|l|}{ Scale: Excellent $=5$ through Poor $=1$} \\
\hline \multicolumn{3}{|l|}{ How would you rate the quality of the following: } \\
\hline Overall importance of topics & 4.49 & 4.49 \\
\hline Quality of content & 4.38 & 4.32 \\
\hline Opportunities to be actively engaged & 4.67 & 4.66 \\
\hline Organization of sessions & 4.08 & 4.49 \\
\hline Communication skills of presenters & 4.64 & 4.52 \\
\hline Amount of time allocated for planning work & 4.33 & 4.23 \\
\hline Opportunities to interact with other participants & 4.69 & 4.84 \\
\hline Opportunities to get feedback from experts/facilitators & 4.26 & 4.36 \\
\hline \multicolumn{3}{|l|}{ Goal Attainment } \\
\hline \multicolumn{3}{|l|}{ Scale: $5=$ To a great extent through $1=$ Not at all } \\
\hline \multicolumn{3}{|l|}{ To what extent do you think the following workshop goals were achieved: } \\
\hline $\begin{array}{l}\text { Participants will be able to list and briefly describe important principles } \\
\text { about how students learn and especially how students learn engincering }\end{array}$ & 4.10 & 3.73 \\
\hline $\begin{array}{l}\text { Participants will be able to list and briefly describe common methods used } \\
\text { in educational research }\end{array}$ & 3.87 & 4.15 \\
\hline Participants will be able to read and interpret educational research articles & 3.97 & 3.97 \\
\hline $\begin{array}{l}\text { Participants will be able to conduct informal or formal educational } \\
\text { research at their respective campuses }\end{array}$ & 3.79 & 3.98 \\
\hline $\begin{array}{l}\text { Participants will be able to use the results of educational research to im- } \\
\text { prove their curricula and/or teaching methods }\end{array}$ & 3.87 & N/A \\
\hline
\end{tabular}


TABLE 9.3

Self-Reported Post-Knowledge and Gains: 2004-2005 Cohort Results on Comparable ltems

\begin{tabular}{|l|c|c|}
\hline Item & $\begin{array}{c}\text { Gain } \\
\mathbf{2 0 0 4}\end{array}$ & $\begin{array}{c}\text { Gain } \\
\mathbf{2 0 0 5}\end{array}$ \\
\hline Content Familiarity & & \\
\hline Scale: 5 = Know a lot through 1 = Know very little & & \\
\hline How would you rate your knowledge of the following: & & \\
\hline How engineering research and educational research differ & 0.41 & 1.16 \\
\hline Designing rescarch questions with educational issues in mind & 1.36 & 1.18 \\
\hline Quantitative research methods in educational settings & 0.97 & 1.07 \\
\hline Qualitative rescarch methods in educational settings & 0.74 & 0.79 \\
\hline Understanding educational studies & 0.82 & 0.97 \\
\hline Applying educational studies & 0.69 & 0.79 \\
\hline Venues for presenting results of educational research (journals and conferences) & 1.08 & 0.85 \\
\hline More Specific Content Knowledge & & \\
\hline Scale: 5 = Can define well through 1 = Cannot define at all & & \\
\hline How familiar are you with the following terms or names: & & \\
\hline Cognitive apprenticeship & 2.33 & 1.88 \\
\hline Epistemology & 1.21 & 1.24 \\
\hline Construct validity & 1.36 & 1.12 \\
\hline Design experiment & 0.38 & 0.35 \\
\hline Mental models & 1.36 & 0.74 \\
\hline Self-Reported Knowledge (open-ended) & & \\
\hline Scale: 5 = Can answer well through 1 = Cannot answer at all & & \\
\hline How well can you answer the following questions: & & \\
\hline What are standards for "rigorous research" in the STEM disciplines? & 2.36 & 2.42 \\
\hline $\begin{array}{l}\text { What do you sce as the relationship between thcory and measurement in } \\
\text { educational research? }\end{array}$ & 1.51 & 1.53 \\
\hline $\begin{array}{l}\text { Describe the differences among experimental, relational, and descriptive } \\
\text { studies. }\end{array}$ & 1.56 & 1.25 \\
\hline Thoughts on Leaving & & \\
\hline Scale: 5 = Very comfortable through 1 = Not at all comfortable & & \\
\hline How comfortable do you now fecl about designing educational research studics? & 0.83 & 0.99 \\
\hline & & \\
\hline
\end{tabular}


The following day, several individuals indicated understanding and acceptance of generalizability as an important goal of rigorous educational research. When the groups were asked to identify the characteristics of a good research question, they listed attributes including generalizability, "universal significance," contribution to society, and the ability to generate more questions. The facilitator then asked the groups to clarify the meaning of significance. They volunteered interpretations such as personal significance, passion, publication, and relevance to "something bigger."

By the end of the workshop, participants were still considering generalizability. When the facilitator introduced qualitative research methods, one participant asked how the focus on understanding a specific setting related to the need for generalizability stressed earlier in the week. During the final poster presentations, another participant explained his motivation for involving participants from three universities in his research project. He explained that, in his case, the small class sizes at each of the institutions limited the potential generalizability of his research, but combining studies would make his results more applicable to a variety of settings.

The participants also displayed resistance to the idea of choosing a theoretical framework and measurements-again, issues that engineers do not have to grapple with in their disciplinary research.

\section{Conclusion}

It may be useful to think of faculty participation in the teaching and learning process as a continuum with excellent teaching at one end and rigorous educational research on the other. Additionally, faculty developers may want to think about how to prepare interested faculty to venture into the realm of educational research, perhaps to "go meta" with their modest SoTL research.

When developing programs to help faculty move toward educational research, we should keep in mind the paradigm differences between disciplinary research and educational research. Facilitating paradigm shifts may be as (or more) important to making the transition to educational researcher as is obtaining the requisite knowledge and skills. Our experience with the RREE project has shown that paradigm shifts are difficult for faculty to make, and it takes time to understand the design and decision-making steps involved in educational research that may be unnecessary in other disciplines. Therefore, programs that prepare faculty to make this transition need to be long term. A few hours or a few days is too short a time period for faculty to assimilate these changes. 
Lastly, we hope to spur discussions about new directions for SoTL. While respecting the value of the personal studies usually conducted in SoTL, we suggest that some faculty may be interested in conducting research that can yield findings useful to educational or learning theory. This kind of work can involve truly interdisciplinary collaborations, with disciplinary experts informing the work of learning scientists, and learning scientists informing the work of disciplinary experts.

\section{Note}

We wish to thank the National Science Foundation for supporting this work through grant number DUE-0341127, which funds Conducting Rigorous Research in Engineering Education: Creating a Community of Practice, also called the RREE project. We also thank Dr. Norman Fortenberry, of the $\mathrm{Na}$ tional Academy of Engineering's Center for the Advancement of Scholarship in Engineering Education, for his partnership in this project. Special thanks goes to the RREE Executive Committee who jointly developed the "SoTL to educational research" model at the June 11,2005, executive committee meeting. In addition to authors Streveler and Smith, the RREE Executive Committee members who were part of this discussion are Robin Adams, Nancy Chism, George B. Forsythe, Frank Huband, Marcia Mentkowksi, Ron Miller, and Marilla Svinicki. Appreciation goes to Debra Fowler, who assisted with evaluation of the RREE in 2004, and Maura Borrego, who contributed to the 2005 evaluation and who also helped to create the SoTL to educational research model. Our thanks also go to Mary Deane Sorcinelli, who is a member of the RREE Executive Committee, but who was not able to attend the June 11,2005 , meeting.

\section{References}

Boyer, E. L. (1990). Scholarship reconsidered: Priorities of the professoriate. Princeton, NJ: Carnegic Foundation for the Advancement of Teaching.

Brown, J. S., Collins, A., \& Duguid, P. (1989, January/February). Situated cognition and the culture of learning. Educational Researcher, 18(1), 32-42.

Collins, A., Brown, J. S., \& Newman, S. E. (1989). Cognitive apprenticeship: Teaching and crafts of reading, writing, and mathematics. In L. B. Resnick (Ed.), Knowing, lcarning, and instruction: Essays in honor of Robert Glaser (pp. 453-494). Hillsdale, NJ: Lawrence Erlbaum. 
Felder, R. M., Sheppard, S. D., \& Smith, K. A. (2005, January). Guest editor's foreword: A new journal for a field in transition. Journal of Engincering Education, 94(1), 7-10.

Gabriele, G. A. (2005, July). Guest editorial: Advancing engineering education in a flattened world. Journal of Engineering Education, 94(3), 285-286.

Haghighi, K. (2005, October). Guest editorial: Quiet no longer: Birth of a new discipline. Journal of Engincering Education, 94(4), 351-353.

Huber, M. T., \& Hutchings, P. (2005). The advancement of learning: Building the teaching commons. San Francisco, CA: Jossey-Bass.

Hutchings, P., \& Shulman, L. S. (1999, September/October). The scholarship of teaching: New elaborations, new developments. Change, 31(5), 10-15.

Paulsen, M. P. (2001). The relationship between research and the scholarship of teaching. In C. Kreber (Ed.), New directions for teaching and learning: No. 86. Scholarship revisited: Perspectives on the scholarship of teaching (pp. 19-29). San Francisco, CA: Jossey-Bass.

Schroeder, C. M. (2005, October). Going "meta" with SoTL: Research-based frameworks as the missing link. Paper presented at the 30 th annual conference of the Professional and Organizational Development Network in Higher Education, Milwaukce, WI.

Sorcinelli, M. D., Austin, A. E., Eddy, P. L., \& Beach, A. L. (2006). Creating the future of faculty development: Learning from the past, understanding the present. Bolton, MA: Anker. 